\title{
EFFECT OF ADDING SOME VEGETABLE OILS TO POLLEN SUBSTITUTES ON PALATABILITY AND PREFERENCE OF HONEY BEE, APIS MELLIFERA L. COLONIES. \\ Moustafa, A.M. \\ Apiculture Department, Plant Protection Research Institute, Agricultural Research Centre, Dokki, Giza, Egypt
}

\begin{abstract}
Little is known about which commercial vegetable oils could be used as an ingredient in improving artificial feedstuffs for honey bees. To test whether the oils are palatable or whether honey bees showed a preference, they were added at $1 \%$ and $2 \%$ concentration to pollen substitute known to be attractive to bees. Seven different vegetable oils, only linseed was consumed by bees at a significantly greater rate than others followed by almond and coconut. Other oils added to pollen substitute that had higher consumption rates by colonies than pollen substitute without oil were (highest to lowest): corn,

Soybean, Palm and sunflower oils. Obtained results show the superiority of diet consumption for the workers which feed on pollen substitute containing linseed oil at 1 and $2 \%$ concentrations (109.43 and $110.11 \mathrm{mg}$ ), respectively over any all other oils and control. The percentages of deviation from control (without oil) $(+68.43,69.46)$, $(+55.70,57.27),(+55.37,56.56),(+35.59,36.78),(+26.20,27.18),(+21.94,23.03)$ and $(+11.54,11.98)$ were recorded in case of linseed, almond, coconut, corn, soybean, palm and sunflower oils at 1 and $2 \%$ concentrations, respectively.
\end{abstract}

Keywords: Honey bee, pollen substitute, vegetable oils, palatability

\section{INTRODUCTION}

Pollen in the form of bee bread is the honey bee's main source of protein and it also provides fats or lipids, minerals, and vitamins. The protein that pollen provides is vital to brood production and the development of young bees. The quality of diet influences colony health and strength, especially for colonies preparing for over-wintering and starting population build up in the early spring. Dietary problems have been one of several factors linked to declines in honeybee health and populations in North American and Europe. Absence, shortage or even poor quality of pollen results in stunted growth, inferior weight gain of young bees, reduced longevity and poor development of hypopharyngeal glands, leading to insufficient royal jelly production to support normal growth and development of larvae, and normal egg production by the queen (Hays, 1984 and Zaytoon et al., 1988). These effects can result in poor colony development and production.

During the shortage or complete absence of pollen (particularly early in the season), or in the presence of only poor quality pollen, beekeepers often feed colonies of honeybees with either pollen substitute (with no pollen) or supplement (with pollen). Ideally, these are materials that provide required nutrients to the bees. There are disadvantages to pollen feeding. Beekeepers often do not collect pollen to add to diets, and commercially available pollen is costly. Furthermore, it may be contaminated with various honeybee 
pathogens (Herbert and Shimanuki, 1980) or may contain toxic pollen (Schmidt et al., 1987). Ideal pollen substitutes would be readily accepted by honeybees year-round, healthful, rich enough to meet all their nutritional requirements, and inexpensive. To develop such ideal diets has been one of the most enduring apicultural research problems (Haydak, 1945, Abdellatif et al., 1971, Schmidt et al., 1987, Baidya et al., 1993, Herbert, 2000, Nabors, 2000, van der Steen, 2007, DeGrandi-Hoffman et al., 2008, De Jong et al., 2009 and Saffari et al., 2010).

So the beekeepers are concerned with providing an effective pollen supplements or substitutes, when natural pollen supplies are insufficient to promote colony development and health. Pollen supplements contain honey bee-collected pollen (5-10\%) mixed with other protein sources such as yeast, soybean flour and/or other materials. Pollen substitutes replace pollen totally with nutritionally adequate materials (Herbet, 1992).

In Egypt, several beekeepers use to feed their bee colonies on sugar syrup during late autumn and early spring to accelerate brood rearing. This feed stimulates the oviposition (Doull, 1973) but it has usually a limited effect due to lack of pollen. The probability of proteinious feeding during autumn is essential to increase the ability of brood rearing and to prepare the bees for over wintering (Omar, 1989). Moreover, obtaining high population of bees in the spring is of a particular interest to beekeepers.

The useful pollen substitute should stimulate colony growth and support aspects of worker quality, such as high brood survival and long adult life (Winston et al., 1983). Meanwhile, the pollen substitute should be acceptable and has the necessary stimulation for bees to consume their food (Doull, 1973). Successful artificial diets must meet three essential criteria. It must be attractive to foraging bees. It must provide all nutrients essential for a rapidly growing colony other than energy including amino acids, fatty acids, minerals, vitamins and hormone precursors. It must not include toxic substances such as starch and oligosaccharides. Honey bees usually prefer pollen over pollen substitutes, not because pollen is more nutritious, but because there are substances in pollen making it more attractive. Little is known about which commercial oils could be used as an ingredient in improving artificial feedstuffs for honey bees.

The aim of present investigation was conducted to evaluate the effect of some vegetable oils addition to pollen substitute on palatability and preference of honey bee colonies.

\section{MATERIALS AND METHODS}

The experiments were carried out in the apiary yard at Refa location, Assiut Governorate, Upper Egypt, during October, 2013.

\section{Experimental honey bee colonies:}

Five honey bee colonies of the first hybrid of Carniolan honey bee, Apis mellifera carnica Pollmann, nearly in equal strength, contained stored pollen and honey, and headed with sister queens were initiated. 


\section{Diet preparing and administration:}

The diet in the present study used according to Mustafa (2000). It contains of 5 parts of powdered sugar, 3 parts defatted soybean meal, 1 part brewer's dried yeast, 0.5 part skimmed milk powder. The diet was offered in cake form at the rate of $50 \mathrm{gm}$. per colony. It was offered and renewed continuously to each colony at 3 days. The cakes were placed over the brood nest in perforated polyethylene bags to reduce the water evaporation.

The vegetable oils used:

Seven vegetable oils purchased commercially; linseed, coconut, sunflower, soybean, almond, Palm and corn were used at the concentrations of $1 \%$ and $2 \%$ for each oil added to the diet.

Determination of diet consumption:

Throughout the investigation, the food consumption was recorded by calculating the difference in the weight of diet before and after feeding (gm./colony).This procedure was made several times at 3days interval of feeding. Using both palatability and preference testing methodologies to determine the attractiveness of diets to bees gave the same result (Manning et al., 2010).

Statistical analysis:

Analysis of variance (ANOVA) was carried out using MSTAT-C software program (MSTAT-C, Michigan State University Version 2.10) and least significant difference (LSD) values were calculated when F-value were significant for times of introduction effects according to the method of Waller and Duncan (Waller and Duncan, 1969).

\section{RESULTS AND DISCUSSIONS:}

\section{Diet consumption:}

During feeding consumption tests, honey bee colonies were given a choice among seven types of oils at the concentrations of $1 \%$ and $2 \%$ of each oil added to the diet. The total diet consumed by the colony was calculated after the 23 days. The colonies showed consumption preference for some oil types than others added to the diet. Also, the deviation in the total consumption of each oil out from that without oil.

Calculated amounts of diet consumed per oil added to the diet indicated different preference. The amount of pollen substitute consumption differed significantly over all the compared oils. Total and mean consumption (gm. /colony) of diet with different additional oils at $1 \%$ concentration were (109.43, 13.68), (101.17, 12.65), (100.95,12.62), (88.10,11.01), (82.00,10.25), (79.23, 9.90), $(72.47,9.06)$ and $(64.97,8.12)$ for linseed; almond; coconut; corn; soybean; palm and sunflower oils and control, respectively. The same trend was noticed concerning to $2 \%$ concentration of the same sort oils and control, the total and mean of pollen substitute consumption were $(110.11,13.76)$, (102.19, 12.77), (101.72, 12.72), (88.87,11.11), (82.64, 10.33, (79.94, 9.99), $(72.74,9.07)$ and $(64.97,8.12)$, respectively (Table 1$)$. 
Table (1): diet consumption by honey bee colonies containing different vegetable oils.

\begin{tabular}{|c|c|c|c|c|c|c|c|c|c|}
\hline \multirow{2}{*}{ Date } & \multirow[b]{2}{*}{$\begin{array}{l}\text { Oil } \\
\text { con. } \\
(\%)\end{array}$} & \multicolumn{8}{|c|}{ Diet consumption (gm./colony/3 days) Means \pm SE } \\
\hline & & Linseed & almond & coconut & corn & soybean & Palm & $\begin{array}{l}\text { Sunfl- } \\
\text { ower }\end{array}$ & Control \\
\hline \multirow{2}{*}{$4 / 10$} & 1 & $\begin{array}{c}12.975 \mathrm{~A} \\
\pm 3.080\end{array}$ & $\begin{array}{c}12.316 \mathrm{~B} \\
\pm 3.130\end{array}$ & $\begin{array}{c}12.114 \mathrm{~B} \\
\pm 3.010\end{array}$ & $\begin{array}{c}11.098 \mathrm{C} \\
\pm 1.133\end{array}$ & $\begin{array}{c}9.725 \mathrm{DE} \\
\pm 2.731\end{array}$ & $\begin{array}{c}10.008 \mathrm{D} \\
\pm 3.251\end{array}$ & $\begin{array}{c}9.317 \mathrm{DE} \\
\pm 1.472\end{array}$ & $\begin{array}{l}9.125 \mathrm{E} \\
\pm 3.712\end{array}$ \\
\hline & 2 & $\begin{array}{c}13.132 \mathrm{~A} \\
\pm 4.133\end{array}$ & $\begin{array}{c}12.515 \mathrm{~B} \\
\pm 2.241\end{array}$ & $\begin{array}{c}12.220 \mathrm{C} \\
\pm 3.210\end{array}$ & $\begin{array}{c}11.305 \mathrm{D} \\
\pm 3.059\end{array}$ & $\begin{array}{l}9.907 \mathrm{~F} \\
\pm 2.952\end{array}$ & $\begin{array}{c}10.190 \mathrm{E} \\
\pm 4.133\end{array}$ & $\begin{array}{l}9.483 \mathrm{G} \\
\pm 3.090\end{array}$ & $\begin{array}{l}9.125 \mathrm{H} \\
\pm 3.712\end{array}$ \\
\hline \multirow{2}{*}{$7 / 10$} & 1 & $\begin{array}{c}13.431 \mathrm{~A} \\
\pm 2.588\end{array}$ & $\begin{array}{c}12.625 \mathrm{~B} \\
\pm 1.472\end{array}$ & $\begin{array}{c}12.512 \mathrm{~B} \\
\pm 4.016\end{array}$ & $\begin{array}{c}11.120 \mathrm{C} \\
\pm 1.589\end{array}$ & $\begin{array}{c}10.015 \mathrm{D} \\
\pm 3.251\end{array}$ & $\begin{array}{c}10.150 \mathrm{D} \\
\pm 4.000\end{array}$ & $\begin{array}{l}8.993 \mathrm{E} \\
\pm 1.225\end{array}$ & $\begin{array}{l}7.723 \mathrm{~F} \\
\pm 2.503\end{array}$ \\
\hline & 2 & $\begin{array}{c}13.550 \mathrm{~A} \\
\pm 2.905\end{array}$ & $\begin{array}{c}12.715 \mathrm{~B} \\
\pm 1.034\end{array}$ & $\begin{array}{c}12.700 \mathrm{~B} \\
\pm 3.003\end{array}$ & $\begin{array}{r}11.110 \mathrm{C} \\
\pm 4.000\end{array}$ & $\begin{array}{c}10.150 \mathrm{D} \\
\pm 3.333\end{array}$ & $\begin{array}{c}10.170 \mathrm{D} \\
\pm 3.291\end{array}$ & $\begin{array}{l}9.000 \mathrm{E} \\
\pm 2.059\end{array}$ & $\begin{array}{l}7.723 \mathrm{~F} \\
\pm 2.503\end{array}$ \\
\hline \multirow{2}{*}{$10 / 10$} & 1 & $\begin{array}{c}13.630 \mathrm{~A} \\
\pm 2.811\end{array}$ & $\begin{array}{c}12.630 \mathrm{AB} \\
\pm 1.225\end{array}$ & $\begin{array}{c}12.750 \mathrm{~A} \\
\pm 3.282\end{array}$ & $\begin{array}{r}10.989 \mathrm{BC} \\
\pm 2.273\end{array}$ & $\begin{array}{c}10.340 \mathrm{CD} \\
\pm 1.980\end{array}$ & $\begin{array}{c}9.830 \mathrm{CD} \\
\pm 3.008\end{array}$ & $\begin{array}{c}9.027 \mathrm{DE} \\
\pm 2.391\end{array}$ & $\begin{array}{l}8.005 \mathrm{E} \\
\pm 2.400\end{array}$ \\
\hline & 2 & $\begin{array}{c}13.550 \mathrm{~A} \\
\pm 2.472\end{array}$ & $\begin{array}{c}12.700 \mathrm{AB} \\
\pm 2.381\end{array}$ & $\begin{array}{c}12.675 \mathrm{AB} \\
\pm 4.046\end{array}$ & $\begin{array}{r}11.110 \mathrm{BC} \\
\pm 3.381\end{array}$ & $\begin{array}{c}10.400 \mathrm{CD} \\
\pm 3.109\end{array}$ & $\begin{array}{c}10.015 \text { CD } \\
\pm 317\end{array}$ & $\begin{array}{c}9.019 \mathrm{DE} \\
\pm 4.352\end{array}$ & $\begin{array}{l}8.005 \mathrm{E} \\
\pm 2.400\end{array}$ \\
\hline \multirow{2}{*}{$13 / 10$} & 1 & $\begin{array}{c}13.573 \mathrm{~A} \\
\pm 1.855\end{array}$ & $\begin{array}{c}12.650 \mathrm{~A} \\
\pm 4.442\end{array}$ & $\begin{array}{c}13.008 \mathrm{~A} \\
\pm 3.152\end{array}$ & $\begin{array}{c}10.791 \mathrm{~B} \\
\pm 3.371\end{array}$ & $\begin{array}{c}10.718 \mathrm{~B} \\
\pm 2.281\end{array}$ & $\begin{array}{l}9.751 \mathrm{~B} \\
\pm 3.211\end{array}$ & $\begin{array}{c}9.000 \mathrm{BC} \\
\pm 1.009\end{array}$ & $\begin{array}{l}7.813 \mathrm{C} \\
\pm 1.935\end{array}$ \\
\hline & 2 & $\begin{array}{c}13.615 \mathrm{~A} \\
\pm 5.333\end{array}$ & $\begin{array}{c}12.673 \mathrm{AB} \\
\pm 3.187\end{array}$ & $\begin{array}{c}12.950 \mathrm{~A} \\
\pm 2.301\end{array}$ & $\begin{array}{c}10.999 \mathrm{BC} \\
\pm 3.444\end{array}$ & $\begin{array}{c}10.750 \mathrm{CD} \\
\pm 2.050\end{array}$ & $\begin{array}{c}9.907 \text { CD } \\
\pm 1.358\end{array}$ & $\begin{array}{c}9.000 \mathrm{DE} \\
\pm 3.111\end{array}$ & $\begin{array}{l}7.813 \mathrm{E} \\
\pm 1.935\end{array}$ \\
\hline \multirow{2}{*}{$16 / 10$} & 1 & $\begin{array}{c}13.798 \mathrm{~A} \\
\pm 3.898\end{array}$ & $\begin{array}{c}12.538 \mathrm{AB} \\
\pm 3.300\end{array}$ & $\begin{array}{c}12.730 \mathrm{AB} \\
\pm 3.112\end{array}$ & $\begin{array}{c}11.013 \mathrm{BC} \\
\pm 3.672\end{array}$ & $\begin{array}{c}10.517 \text { CD } \\
\pm 3.100\end{array}$ & $\begin{array}{c}9.740 \text { CD } \\
\pm 1.411\end{array}$ & $\begin{array}{c}8.973 \mathrm{DE} \\
\pm 1.981\end{array}$ & $\begin{array}{l}8.031 \mathrm{E} \\
\pm 2.337\end{array}$ \\
\hline & 2 & $\begin{array}{c}13.907 \mathrm{~A} \\
\pm 2.199\end{array}$ & $\begin{array}{c}12.645 \mathrm{AB} \\
\pm 3.051\end{array}$ & $\begin{array}{c}12.800 \mathrm{AB} \\
\pm 2.232\end{array}$ & $\begin{array}{c}11.115 \mathrm{BC} \\
\pm 3.356\end{array}$ & $\begin{array}{c}10.666 \text { CD } \\
\pm 4.205\end{array}$ & $\begin{array}{c}9.878 \mathrm{CDE} \\
\pm 2.224\end{array}$ & $\begin{array}{c}8.961 \mathrm{DE} \\
\pm 2.000\end{array}$ & $\begin{array}{l}8.031 \mathrm{E} \\
\pm 2.337\end{array}$ \\
\hline \multirow{2}{*}{$19 / 10$} & 1 & $\begin{array}{c}13.923 \mathrm{~A} \\
\pm 1.340\end{array}$ & $\begin{array}{c}12.669 \mathrm{AB} \\
\pm 2.381\end{array}$ & $\begin{array}{c}12.480 \mathrm{AB} \\
\pm 2.013\end{array}$ & $\begin{array}{c}11.009 \mathrm{BC} \\
\pm 2.281\end{array}$ & $\begin{array}{c}10.490 \mathrm{BC} \\
\pm 2.009\end{array}$ & $\begin{array}{c}9.824 \mathrm{CD} \\
\pm 2.371\end{array}$ & $\begin{array}{l}8.919 \mathrm{D} \\
\pm 3.305\end{array}$ & $\begin{array}{l}8.030 \mathrm{D} \\
\pm 3.511\end{array}$ \\
\hline & 2 & $\begin{array}{c}14.115 \mathrm{~A} \\
\pm 3.553\end{array}$ & $\begin{array}{c}12.912 \mathrm{AB} \\
\pm 4.555\end{array}$ & $\begin{array}{c}12.619 \mathrm{AB} \\
\pm 4.125\end{array}$ & $\begin{array}{c}11.128 \mathrm{BC} \\
\pm 4.009\end{array}$ & $\begin{array}{c}10.580 \mathrm{CD} \\
\pm 3.304\end{array}$ & $\begin{array}{c}9.807 \mathrm{CDE} \\
\pm 3.111\end{array}$ & $\begin{array}{c}9.031 \mathrm{DE} \\
\pm 2.113\end{array}$ & $\begin{array}{l}8.030 \mathrm{E} \\
\pm 3.511\end{array}$ \\
\hline \multirow{2}{*}{$22 / 10$} & 1 & $\begin{array}{c}14.007 \mathrm{~A} \\
\pm 3.208\end{array}$ & $\begin{array}{c}12.817 \mathrm{AB} \\
\pm 2.381\end{array}$ & $\begin{array}{c}12.540 \mathrm{AB} \\
\pm 3.141\end{array}$ & $\begin{array}{c}11.031 \mathrm{BC} \\
\pm 2.303\end{array}$ & $\begin{array}{l}10.000 \mathrm{C} \\
\pm 4.500\end{array}$ & $\begin{array}{l}9.945 \mathrm{C} \\
\pm 1.000\end{array}$ & $\begin{array}{c}9.111 \mathrm{ED} \\
\pm 2.181\end{array}$ & $\begin{array}{l}7.950 \mathrm{D} \\
\pm 2.604\end{array}$ \\
\hline & 2 & $\begin{array}{c}14.120 \mathrm{~A} \\
\pm 2.007\end{array}$ & $\begin{array}{c}13.000 \mathrm{AB} \\
\pm 2.449\end{array}$ & $\begin{array}{c}12.773 \mathrm{AB} \\
\pm 4.000\end{array}$ & $\begin{array}{c}11.117 \mathrm{BC} \\
\pm 3.604\end{array}$ & $\begin{array}{l}9.973 \mathrm{C} \\
\pm 1.839\end{array}$ & $\begin{array}{l}9.952 \mathrm{C} \\
\pm 2.009\end{array}$ & $\begin{array}{c}9.124 \mathrm{CD} \\
\pm 2.035\end{array}$ & $\begin{array}{l}7.950 \mathrm{D} \\
\pm 2.604\end{array}$ \\
\hline \multirow{2}{*}{$25 / 10$} & 1 & $\begin{array}{c}14.097 \mathrm{~A} \\
\pm 5.311\end{array}$ & $\begin{array}{c}12.920 \mathrm{AB} \\
\pm 3.100\end{array}$ & $\begin{array}{c}12.815 \mathrm{AB} \\
\pm 4.060\end{array}$ & $\begin{array}{c}11.053 \mathrm{BC} \\
\pm 1.405\end{array}$ & $\begin{array}{c}10.195 \mathrm{CD} \\
\pm 2.223\end{array}$ & $\begin{array}{c}9.981 \mathrm{CD} \\
\pm 2.050\end{array}$ & $\begin{array}{c}9.130 \mathrm{CD} \\
\pm 2.000\end{array}$ & $\begin{array}{l}8.297 \mathrm{D} \\
\pm 3.009\end{array}$ \\
\hline & 2 & $\begin{array}{c}14.116 \mathrm{~A} \\
\pm 4.209\end{array}$ & $\begin{array}{c}13.025 \mathrm{~A} \\
\pm 4.305\end{array}$ & $\begin{array}{c}12.987 \mathrm{~A} \\
\pm 4.214\end{array}$ & $\begin{array}{c}10.984 \mathrm{~B} \\
\pm 2.333\end{array}$ & $\begin{array}{c}10.210 \mathrm{BC} \\
\pm 2.180\end{array}$ & $\begin{array}{c}10.017 \mathrm{BCD} \\
\pm 3.110\end{array}$ & $\begin{array}{c}9.125 \mathrm{CD} \\
\pm 2.107\end{array}$ & $\begin{array}{l}8.297 \mathrm{D} \\
\pm 3.009\end{array}$ \\
\hline \multirow{2}{*}{$\begin{array}{c}\text { Tot. } \\
\text { gm./colony/23 } \\
\text { days }\end{array}$} & 1 & 43 & 101.17 & 95 & 88.10 & 00 & 23 & 72.47 & 64.97 \\
\hline & 2 & & 102.19 & 72 & & & & 72.74 & 64.97 \\
\hline \multirow{2}{*}{ Mean } & 1 & $13.68 \mathrm{~A}$ & $12.65 \mathrm{~B}$ & $12.62 \mathrm{~B}$ & $11.01 \mathrm{C}$ & 10.25 D & $9.90 \mathrm{E}$ & $9.06 \mathrm{~F}$ & $8.12 \mathrm{G}$ \\
\hline & 2 & $13.76 \mathrm{~A}$ & $12.77 \mathrm{~B}$ & $12.72 \mathrm{~B}$ & $11.11 \mathrm{C}$ & $10.33 \mathrm{D}$ & $9.99 \mathrm{E}$ & $9.07 \mathrm{~F}$ & $8.12 \mathrm{G}$ \\
\hline \multirow{2}{*}{\begin{tabular}{|l|} 
Deviation to \\
control (\%) \\
\end{tabular}} & 1 & +68.43 & +55.70 & +55.37 & +35.59 & +26.20 & +21.94 & +11.54 & 0.00 \\
\hline & 2 & .46 & +57.27 & +56.56 & +36.78 & +27.18 & +23.03 & $\begin{array}{r}+11.98 \\
\end{array}$ & 0.00 \\
\hline \multicolumn{2}{|c|}{ General Mean } & $13.72 \mathrm{~A}$ & $12.71 \mathrm{~B}$ & 12.67B & $11.06 \mathrm{C}$ & 10.29D & $9.95 \mathrm{E}$ & $9.08 \mathrm{~F}$ & $8.12 \mathrm{G}$ \\
\hline
\end{tabular}




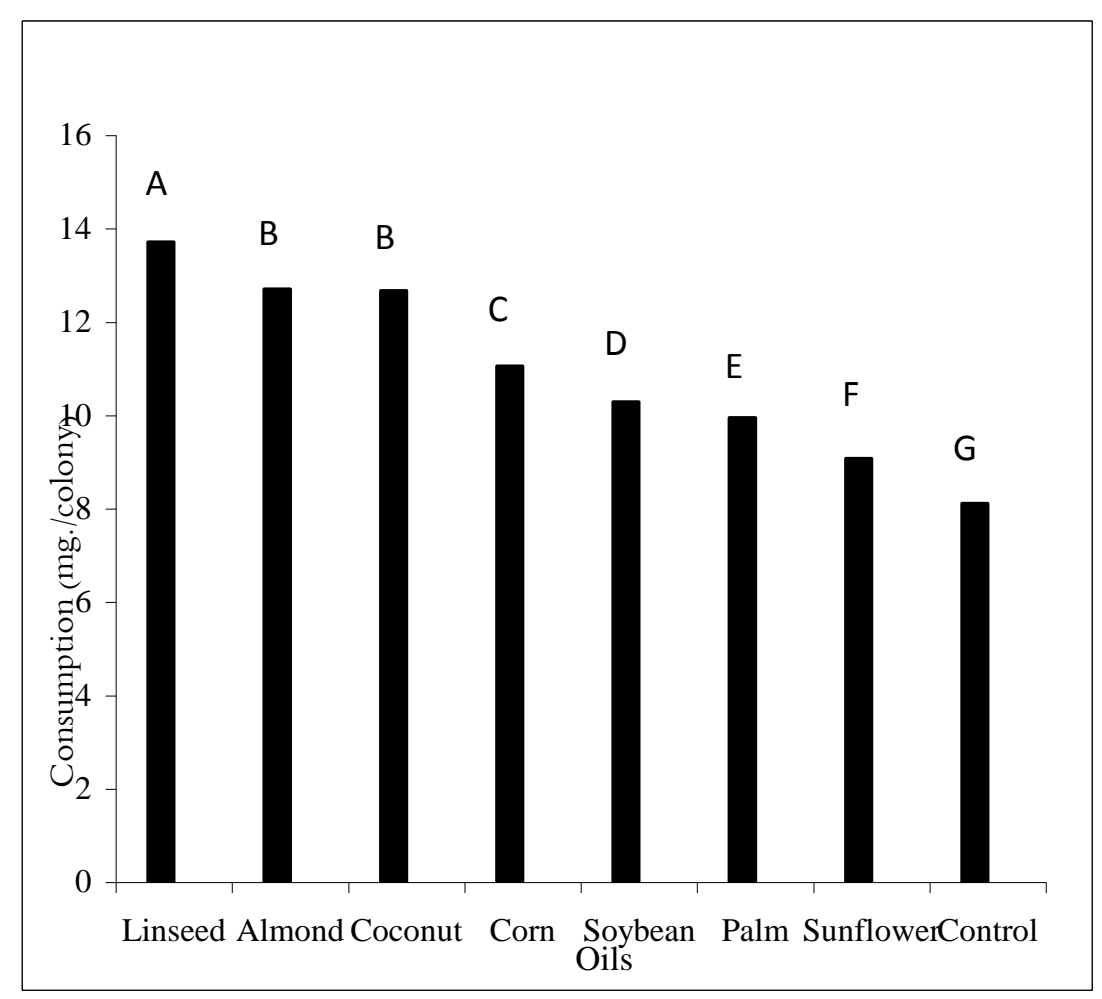

Fig. 1: General mean of pollen substitute consumption by honey bee colonies containing different vegetable oils.

The percentages of deviation from control (without oil); $+68.43,+$ $55.70,+55.37+35.59,+26.20,+21.94$ and $+11.54 \%$ were recorded in case of linseed; almond; coconut; corn; soybean; palm and sunflower oils at $1 \%$ concentration, respectively. Also, the same trend was recorded for $2 \%$ concentration (Figure 1).

Generally, the superiority of pollen substitute consumption for the workers which feeding on pollen substitute added to linseed oil with the general mean was $13.72 \mathrm{gm} . / \mathrm{colony} / 3$ days, followed by almond and coconut oils with general means 12.71 and $12.67 \mathrm{gm}$./colony/3days, respectively over the others. 


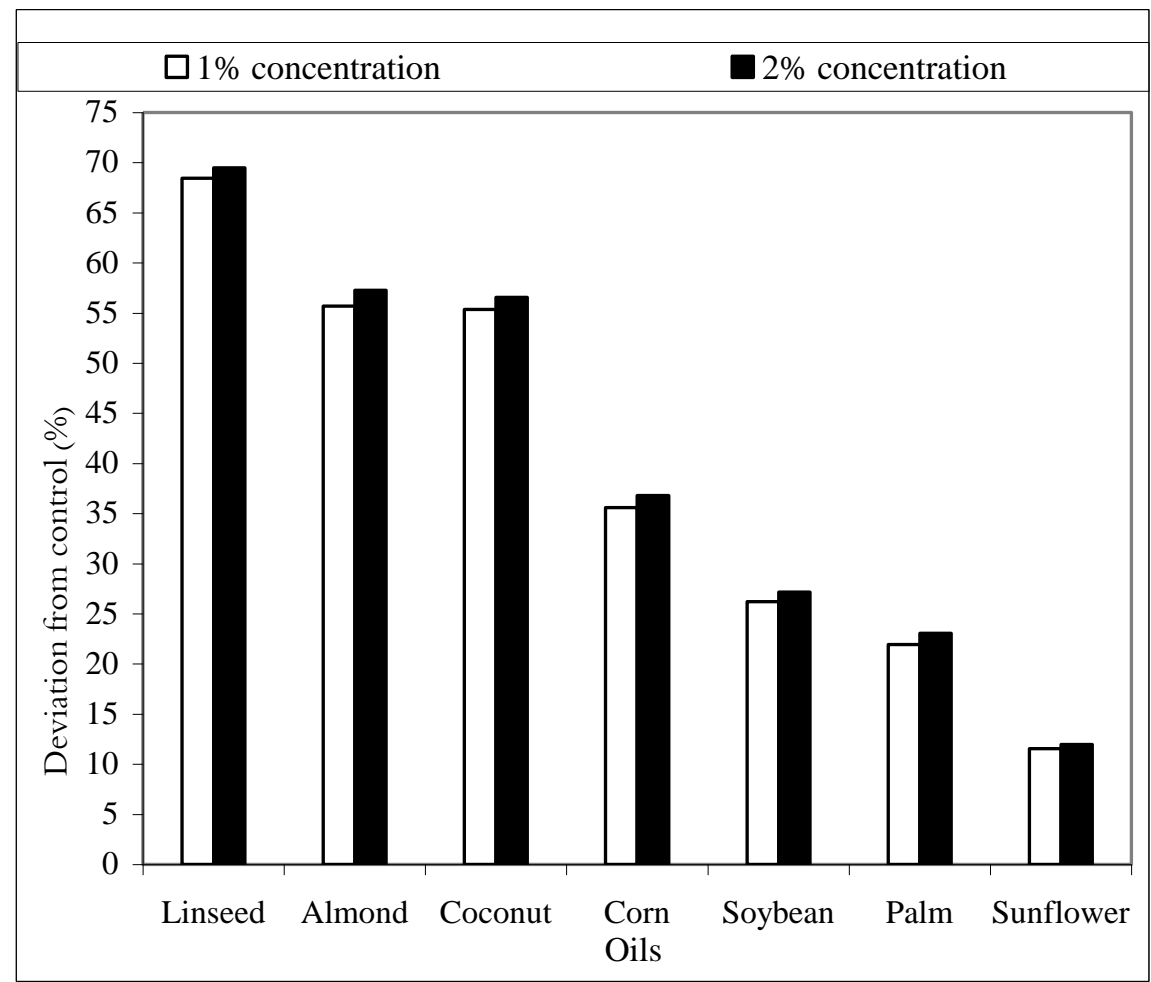

Fig. 2: Deviation from control percentages of pollen substitute consumption by honey bee colonies containing different vegetable oils from control.

Superiority of diet consumption for the workers which feed on pollen substitute containing linseed oil at 1 and 2\% concentrations (109.43 and $110.11 \mathrm{mg}$ ), respectively over any all other oils and control. The percentages of deviation from control $(+68.43,69.46),(+55.70,57.27),(+55.37,56.56)$, $(+35.59,36.78),(+26.20,27.18),(+21.94,23.03)$ and $(+11.54,11.98)$ were recorded in case of linseed; almond; coconut; corn; soybean; palm and sunflower oils at 1 and $2 \%$ concentrations, respectively (Table 1 and figure 2).

Obtained results can be explained as, fatty acids contents of oils may be stimulate and play an important role to attractant honey bee workers to consume pollen substitute.

Nutritional aspect of fatty acids to honey bees is not well known. The C18 (stearic; oleic; linoleic and linolenic) fatty acid group was reported by Hopkins et al., (1969) to be similar to other insect attractants. Teresa, (2006) reported that in most of the examined samples originating from different countries (Poland, Korea and China), the predominating acids were: $\alpha$ linolenic acid (43\%), followed by palmitic acid (28\%) and linoleic acid 
(14\%).Fatty acids are important in the development, nutrition and reproduction of honey bees. The main fatty acids found in 6- day- old larvae and adult bees are oleic, palmitic and stearic but others such as linolenic, myristic, lauric and linoleic are also found in lesser concentrations (Manning, 2001).

Therefore the lipid component of pollen is also important in plantpollination systems. Further, Singh et al., (1999) noted that fatty acids could also be inhibitory in bee gustation (sense of taste) and singled out sunflower lipids which happen to be dominant in myristic acid (Farag et al. 1978). Pollen aromas that attract insects are chiefly carried in pollen lipid (Dobson, 1988).

Many researchers analyzed the chemical composition of studied oils and they determined its fatty acids contents. For instance, Dauqan et al., (2011) found that some fatty acids composition of palm; corn and coconut oils were myristic acid (0.849; 0.0 and 20.572\%), palmitic acid (36.768, 12.427 and $9.161 \%)$, stearic acid $(0.0,11.442$ and $2.936 \%)$, oleic acid $(49.482,36.994$ and $7.211 \%)$, linoleic acid $(11.745,47.189$ and $1.648 \%)$, linolenic acid $(0.539$, 1.312 and $0.0 \%)$ and arachidic acid $(0.161,0.298$ and $0.0 \%)$, respectively. Nehdi (2011) recorded that in soybean oil the percentage of some fatty acids contents were myristic acid (0.12\%); palmitic acid (15.65\%), stearic acid $(4.98 \%)$, oleic acid $(20.98 \%)$, linoleic acid $(50.17 \%)$, linolenic acid $(8.18 \%)$ and arachidic acid (0.55\%). In Egypt, El-Beltagi et al., (2007) studied five linseed cultivars to determine protein profile and contents of fatty acids, unsaponifiable matter, total lipids, total tocopherols, total phenolics and total flavonoids. They reported that the relative proportions of some fatty acids means were myristic acid $(0.7 \%)$, palmitic acid $(7.1 \%)$, stearic acid $(3.7 \%)$, oleic acid $(22.00 \%)$, linoleic acid (18.3\%) and linolenic acid (48.2\%). Also, in a similar study on the chemical characteristics of Egyptian sunflower seeds, Hamed et al., (2012) found that some fatty acids were palmitic acid (6.5\%), stearic acid (7.25\%), oleic acid (32.95\%) and linoleic acid $(52.3 \%)$. For almond oil, Givianrad et al., (2013) determined the fatty acids of wild almond oil. They found that some fatty acids means were myristic acid $(0.15 \%)$, palmitic acid $(13.12 \%)$, stearic acid $(2.78 \%)$, oleic acid $(50.65 \%)$, linoleic acid (29.76\%), linolenic acid (0.59\%) and arachidic acid $(0.17 \%)$.

According to the study by Singh et al., (1999), bees preferred pollens with highest amount of lipids. In addition to variation in lipid content, pollen also varies in the relative proportions of fatty acids as well as in their diversity (Manning, 2001). Fatty acids are important in the reproduction, development, and nutrition of honey bees (Farag et al., 1978 and Manning, 2001). The role of lipids as phagostimulants (attractants) appears to have merit when examples of pollen with nutrient qualities low in protein but high in fat content are far more attractive to foraging honey bees. This example like maize and coriander pollens here in the present study, it recorded the highest attractant pollens than others. Herbert et al. (1980) showed that adding lipid extracts from pollen can increase food consumption and brood rearing in the honey bee colony. 


\section{REFERENCES}

Abdellatif, M. A., F. H. El-Gaiar and N. M. Mohanna (1971). 3 forms of yeast as a pollen substitute. Am. Bee J., 111: 14-15.

Baidya, D. K., M. Sasaki and M. Matsuka (1993). Effect of pollen-substitute feeding site on brood rearing in honeybee colonies. Appl. Ent. Zool., 28: 590-592.

Dauqan, E. M.A., H. A. Sani, A. Abdullah and Z. M. Kasim (2011). Fatty acids composition of four different vegetable oils (red palm olein, palm olein corn oil and coconut oil) by gas chromatography. $2^{\text {nd }}$ International Conference on Chemistry and Chemical Engineering, IPCBEE, 14: 3134.

De Jong, D., E. J. Da Silva, P. G. Kevan and J. L. Atkinson (2009). Pollen substitutes increase honey bee haemolymph protein levels as much as or more than does pollen. J. apic. Res., 48: 34-37.

Degrandi-Hoffman, G.; G. Wardell; F. Ahumada-Segura, T. Rinderer, R. Danka and Pettis J. (2008) - Comparisons of pollen substitute diets for honey bees: consumption rates by colonies and effects on brood and adult populations. J. apic. Res., 47: 265-270.

Dobson, H.E.M. (1988). Survey of pollen and pollenkitt lipids - chemical cues to flower visitors? American Journal of Botany, 75: 170-182.

Doull, K.M. (1973). Relationships between pollen, brood rearing and consumption of pollen supplements by honey bees. Apidologie, 4: 285293.

El-Beltagi, H.S.; Z.A. Salama and D.M. El-Hariri (2007). Evaluation of fatty acids profile and the content of some secondary metabolites in seeds of different flax cultivars (Linum usitatissimum L.). Gen. Appl. Plant physiology, 3: 187-202.

Farag, R.S., A.M. Youssef, M. Ewies and S.A.S. Hallabo (1978). Long-chain fatty acids of six pollens collected by honeybees in Egypt. $\mathrm{J}$ of apic. Res., 17: 100-104.

Givianrad, M.H.; M. Saber-Tehrani and S.A. Jafari Mohammadi (2013). Chemical composition of oils from wild almond (Prunus scoparia) and wild pistachio (Pistacia atlantica). Grasas Y. Aceites, 64: 77-84.

Hamed, S.F., S. M. Wagdy and M.G. Megahed (2012). Chemical characteristics and antioxidant capacity of Egyptian and Chinese sunflower seeds: A case study. Life Sci. J., 9 (2): 320-328.

Haydak, M. H. (1967). Bee nutrition and pollen substitutes. Apiacta, 1: 3-8.

Hays, G. W. J. (1984). Supplemental feeding of honeybees. Am. Bee J., 124: 35-37, 108-109.

Herbert, E.W.J. (2000). Honey bee nutrition, in: Graham, J.M. (Ed.), The Hive and The Honey Bee. Dadant \& Sons. Hamilton, Illinois, pp. 197-233.

Herbert, E.W. (1992). Honey bee nutrition, pp. 197-233. In J.M. Graham [ed.], the hive and the honey bee. Dadant and Sons, Hamilton, IL.

Herbert, E. W. J. and H. Shimanuki (1980). An evaluation of seven potential pollen substitute for honey bees. Am. Bee J., 120: 349-350. 
Herbert, W. E. J., H. Shimanuki, and S. B. Shasha (1980). Brood rearing and food consumption by honeybee colonies fed pollen substitutes supplemented with starch-encapsulated pollen extracts. J. apic. Res., 19: $115-118$.

Hopkins, C.Y.; A.W. Jevans and R. Boch (1969). Occurrence of octadecatrans-2, cis-9, cis-12-trienoic acid in pollen attractive to the honey bee. Canadian Journal of Biochemistry, 47: 433-436.

Manning R, J. Speijers, M. Harvey and JL. Black (2010). Added vegetable and fish oils to low-fat pollen diets: effect on honeybee (Apis mellifera L.) consumption. Australian Journal of Entomology 49, 182-189.

Manning, R. (2001). Fatty acids in pollen: a review of their importance for honey bees. Bee World, 82: 60-75.

Moustafa, A.M. (2000). Influence of some supplementary feed-ing on physiological characters and productivity of honey bees. Ph.D.Thesis, Assiut Univ-ersity, $159 \mathrm{p}$.

Nabors, R. (2000). The effect of spring feeding pollen substitute to colonies of Apis mellifera L. Am. Bee J., 140:322-323.

Nehdi, I. (2011). Characteristics, chemical composition and utilisation of Albizia julibrissin seed oil. J. of Industrial Crops and Products, 33: 3034.

Omar, M.O.M. 1989. The protein quality of bee bread during active season in Assiut area. Assiut J. of Agric. Sci., 20: 339-350.

Schmidt, J. O.; S. C. Thoenes and M. D. Levin (1987). Survival of honey bees, Apis mellifera L. (Hymenoptera: Apidae), fed various pollen sources. Ann. Entomol. Soc. Am., 80: 176-183.

Singh, S.; K. Saini and K.L. Jain (1999). Quantitative comparison of lipids in some pollens and their phagostimulatory effects in honey bees. J. apic. Res., 38: 87-92.

Nicolson, S. W. and H. Human (2013). Chemical composition of the 'low quality' pollen of sunflower (Helianthus annuus, Asteraceae) Apidologie, 4:144.

Szczêsna, T. (2006). Long-chain fatty acids composition of honeybeecollected pollen. Journal of Apicultural Science, 50: 65-79.

Waller, R.A. and D.P. Duncan (1969). A bays rule for symmetric multiple comparison problem. Amer. Stat. Assoc. J., 1485-1503.

Winston, M.L., W.T. Chalmers and P.C. Lee. (1983). Effect of two pollen substitutes on brood mortality and length of adult life in the honey bee. J. apic. Res., 22: 49-52. 
تأثير إضافة بعض الزيوت النباتية لبدائل حبوب اللقاح على إنجذاب وتفضيل طوائف

نحل العسل

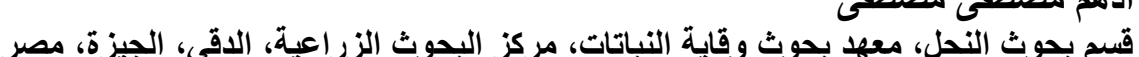
قدم مصم مصطفى مصطفى النحل، معهل

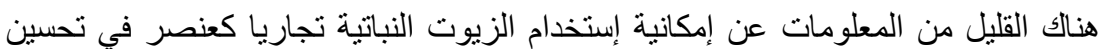

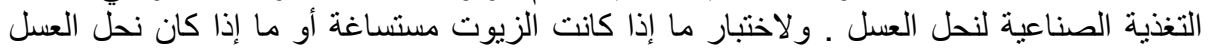

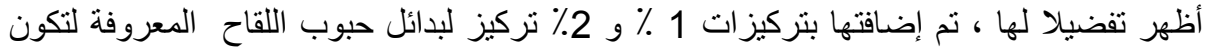

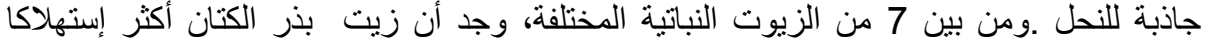

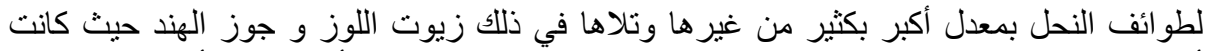

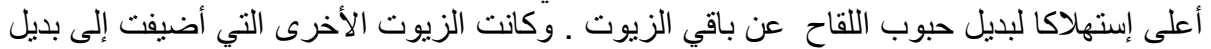

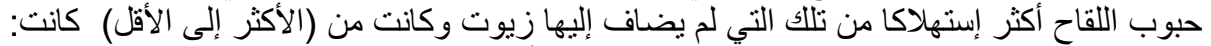

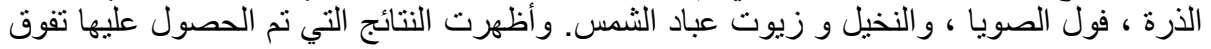

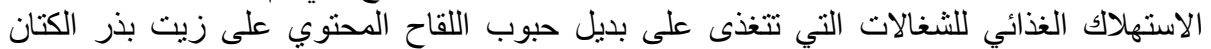

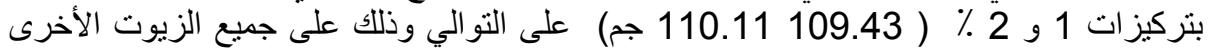

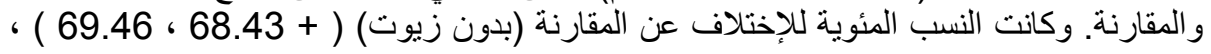

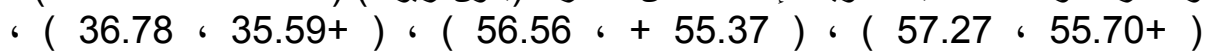

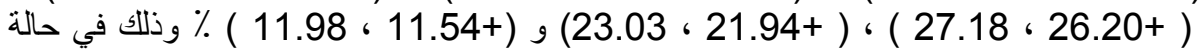
زيوت بذر الكتان ؛ اللوز ؛ جوز الهند ؛ الذرة والصويا والزيوت النخيل و عباد الثمس بتركيزات

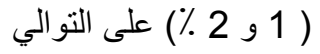

كلية الزراعة - جامعة المنصورة

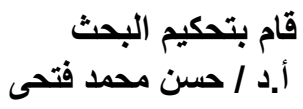

كلية الزراعة - جامعة اسيوط

أ.د / محمد محمد خضيرى ابراهيم 
J. Plant Prot. and Path., Mansoura Univ., Vol.5 (3), March, 2014

Table (1): diet consumption by honey bee colonies containing different vegetable oils.

\begin{tabular}{|c|c|c|c|c|c|c|c|c|c|}
\hline \multirow{2}{*}{ Date } & \multirow[b]{2}{*}{$\begin{array}{l}\text { Oil } \\
\text { con. } \\
(\%)\end{array}$} & \multicolumn{8}{|c|}{ Diet consumption (gm./colony/3 days) Means \pm SE } \\
\hline & & Linseed & almond & coconut & corn & soybean & Palm & & Control \\
\hline \multirow{2}{*}{$4 / 10$} & 1 & $\begin{array}{c}12.975 \mathrm{~A} \\
\pm 3.080\end{array}$ & $\begin{array}{c}12.316 \mathrm{~B} \\
\pm 3.130\end{array}$ & $\begin{array}{c}12.114 \mathrm{~B} \\
\pm 3.010\end{array}$ & $\begin{array}{c}11.098 \mathrm{C} \\
\pm 1.133\end{array}$ & $\begin{array}{c}9.725 \mathrm{DE} \\
\pm 2.731\end{array}$ & $\begin{array}{c}10.008 \mathrm{D} \\
\pm 3.251\end{array}$ & $\begin{array}{c}9.317 \mathrm{DE} \\
\pm 1.472\end{array}$ & $\begin{array}{l}9.125 E \\
\pm 3.712\end{array}$ \\
\hline & 2 & $\begin{array}{c}13.132 \mathrm{~A} \\
\pm 4.133\end{array}$ & $\begin{array}{c}12.515 \mathrm{~B} \\
\pm 2.241\end{array}$ & $\begin{array}{c}12.220 \mathrm{C} \\
\pm 3.210\end{array}$ & $\begin{array}{c}11.305 \mathrm{D} \\
\pm 3.059\end{array}$ & $\begin{array}{l}9.907 \mathrm{~F} \\
\pm 2.952\end{array}$ & $\begin{array}{c}10.190 \mathrm{E} \\
\pm 4.133\end{array}$ & $\begin{array}{l}9.483 \mathrm{G} \\
\pm 3.090\end{array}$ & $\begin{array}{l}9.125 \mathrm{H} \\
\pm 3.712\end{array}$ \\
\hline \multirow{2}{*}{$7 / 10$} & 1 & $\begin{array}{c}13.431 \mathrm{~A} \\
\pm 2.588\end{array}$ & $\begin{array}{c}12.625 \mathrm{~B} \\
\pm 1.472\end{array}$ & $\begin{array}{c}12.512 \text { B } \\
\pm 4.016\end{array}$ & $\begin{array}{c}11.120 \mathrm{C} \\
\pm 1.589\end{array}$ & $\begin{array}{c}10.015 \mathrm{D} \\
\pm 3.251\end{array}$ & $\begin{array}{c}10.150 \mathrm{D} \\
\pm 4.000\end{array}$ & $\begin{array}{l}8.993 \mathrm{E} \\
\pm 1.225\end{array}$ & $\begin{array}{l}7.723 \mathrm{~F} \\
\pm 2.503\end{array}$ \\
\hline & 2 & $\begin{array}{c}13.550 \mathrm{~A} \\
\pm 2.905\end{array}$ & $\begin{array}{c}12.715 \mathrm{~B} \\
\pm 1.034\end{array}$ & $\begin{array}{c}12.700 \mathrm{~B} \\
\pm 3.003\end{array}$ & $\begin{array}{l}11.110 \mathrm{C} \\
\pm 4.000\end{array}$ & $\begin{array}{c}10.150 \mathrm{D} \\
\pm 3.333\end{array}$ & $\begin{array}{c}10.170 \mathrm{D} \\
\pm 3.291\end{array}$ & $\begin{array}{l}9.000 \mathrm{E} \\
\pm 2.059\end{array}$ & $\begin{array}{l}7.723 \mathrm{~F} \\
\pm 2.503\end{array}$ \\
\hline \multirow{2}{*}{$10 / 10$} & 1 & $\begin{array}{c}13.630 \mathrm{~A} \\
\pm 2.811\end{array}$ & $\begin{array}{c}12.630 \mathrm{AB} \\
\pm 1.225\end{array}$ & $\begin{array}{c}12.750 \mathrm{~A} \\
\pm 3.282\end{array}$ & $\begin{array}{c}10.989 \mathrm{BC} \\
\pm 2.273\end{array}$ & $\begin{array}{c}10.340 \text { CD } \\
\pm 1.980\end{array}$ & $\begin{array}{c}9.830 \mathrm{CD} \\
\pm 3.008\end{array}$ & $\begin{array}{c}9.027 \mathrm{DE} \\
\pm 2.391\end{array}$ & $\begin{array}{l}8.005 E \\
\pm 2.400\end{array}$ \\
\hline & 2 & $\begin{array}{c}13.550 \mathrm{~A} \\
\pm 2.472\end{array}$ & $\begin{array}{c}12.700 \mathrm{AB} \\
\pm 2.381\end{array}$ & $\begin{array}{c}12.675 \mathrm{AB} \\
\pm 4.046\end{array}$ & $\begin{array}{c}11.110 \mathrm{BC} \\
\pm 3.381\end{array}$ & $\begin{array}{c}10.400 \text { CD } \\
\pm 3.109\end{array}$ & $\begin{array}{c}10.015 \text { CD } \\
\pm 317\end{array}$ & $\begin{array}{c}9.019 \mathrm{DE} \\
\pm 4.352\end{array}$ & $\begin{array}{l}8.005 E \\
\pm 2.400\end{array}$ \\
\hline \multirow{2}{*}{$13 / 1$} & 1 & $\begin{array}{c}13.573 \mathrm{~A} \\
\pm 1.855\end{array}$ & $\begin{array}{c}12.650 \mathrm{~A} \\
\pm 4.442\end{array}$ & $\begin{array}{c}13.008 \mathrm{~A} \\
\pm 3.152\end{array}$ & $\begin{array}{c}10.791 \mathrm{~B} \\
\pm 3.371\end{array}$ & $\begin{array}{c}10.718 \mathrm{~B} \\
\pm 2.281\end{array}$ & $\begin{array}{l}9.751 \mathrm{~B} \\
\pm 3.211\end{array}$ & $\begin{array}{c}9.000 \mathrm{BC} \\
\pm 1.009\end{array}$ & $\begin{array}{l}7.813 \mathrm{C} \\
\pm 1.935\end{array}$ \\
\hline & 2 & $\begin{array}{c}13.615 \mathrm{~A} \\
\pm 5.333\end{array}$ & $\begin{array}{c}12.673 \mathrm{AB} \\
\pm 3.187\end{array}$ & $\begin{array}{c}12.950 \mathrm{~A} \\
\pm 2.301\end{array}$ & $\begin{array}{c}10.999 \mathrm{BC} \\
\pm 3.444\end{array}$ & $\begin{array}{c}10.750 \mathrm{CD} \\
\pm 2.050\end{array}$ & $\begin{array}{c}9.907 \text { CD } \\
\pm 1.358\end{array}$ & $\begin{array}{c}9.000 \mathrm{DE} \\
\pm 3.111\end{array}$ & $\begin{array}{r}7.813 E \\
\pm 1.935\end{array}$ \\
\hline \multirow{2}{*}{$16 / 10$} & 1 & $\begin{array}{c}13.798 \mathrm{~A} \\
\pm 3.898\end{array}$ & $\begin{array}{c}12.538 \mathrm{AB} \\
\pm 3.300\end{array}$ & $\begin{array}{c}12.730 \mathrm{AB} \\
\pm 3.112\end{array}$ & $\begin{array}{c}11.013 \text { BC } \\
\pm 3.672\end{array}$ & $\begin{array}{c}10.517 \text { CD } \\
\pm 3.100\end{array}$ & $\begin{array}{c}9.740 \text { CD } \\
\pm 1.411\end{array}$ & $\begin{array}{c}8.973 \mathrm{DE} \\
\pm 1.981\end{array}$ & $\begin{array}{l}8.031 E \\
\pm 2.337\end{array}$ \\
\hline & 2 & $\begin{array}{c}13.907 \mathrm{~A} \\
\pm 2.199\end{array}$ & $\begin{array}{c}12.645 \mathrm{AB} \\
\pm 3.051\end{array}$ & $\begin{array}{c}12.800 \mathrm{AB} \\
\pm 2.232\end{array}$ & $\begin{array}{c}11.115 \mathrm{BC} \\
\pm 3.356\end{array}$ & $\begin{array}{c}10.666 \text { CD } \\
\pm 4.205\end{array}$ & $\begin{array}{c}9.878 \mathrm{CDE} \\
\pm 2.224\end{array}$ & $\begin{array}{c}8.961 \mathrm{DE} \\
\pm 2.000\end{array}$ & $\begin{array}{l}8.031 E \\
\pm 2.337\end{array}$ \\
\hline \multirow{2}{*}{$19 / 10$} & 1 & $\begin{array}{c}13.923 \mathrm{~A} \\
\pm 1.340\end{array}$ & $\begin{array}{c}12.669 \mathrm{AB} \\
\pm 2.381\end{array}$ & $\begin{array}{c}12.480 \mathrm{AB} \\
\pm 2.013\end{array}$ & $\begin{array}{c}11.009 \mathrm{BC} \\
\pm 2.281\end{array}$ & $\begin{array}{c}10.490 \mathrm{BC} \\
\pm 2.009\end{array}$ & $\begin{array}{c}9.824 \text { CD } \\
\pm 2.371\end{array}$ & $\begin{array}{l}8.919 \mathrm{D} \\
\pm 3.305\end{array}$ & $\begin{array}{l}8.030 \mathrm{D} \\
\pm 3.511\end{array}$ \\
\hline & 2 & $\begin{array}{c}14.115 \mathrm{~A} \\
\pm 3.553\end{array}$ & $\begin{array}{c}12.912 \mathrm{AB} \\
\pm 4.555\end{array}$ & $\begin{array}{c}12.619 \mathrm{AB} \\
\pm 4.125\end{array}$ & $\begin{array}{c}11.128 \mathrm{BC} \\
\pm 4.009\end{array}$ & $\begin{array}{c}10.580 \text { CD } \\
\pm 3.304\end{array}$ & $\begin{array}{c}9.807 \mathrm{CDE} \\
\pm 3.111\end{array}$ & $\begin{array}{c}9.031 \mathrm{DE} \\
\pm 2.113\end{array}$ & $\begin{array}{l}8.030 \mathrm{E} \\
\pm 3.511\end{array}$ \\
\hline \multirow{2}{*}{$22 / 10$} & 1 & $\begin{array}{c}14.007 \mathrm{~A} \\
\pm 3.208\end{array}$ & $\begin{array}{c}12.817 \mathrm{AB} \\
\pm 2.381\end{array}$ & $\begin{array}{c}12.540 \mathrm{AB} \\
\pm 3.141\end{array}$ & $\begin{array}{c}11.031 \mathrm{BC} \\
\pm 2.303\end{array}$ & $\begin{array}{c}10.000 \mathrm{C} \\
\pm 4.500\end{array}$ & $\begin{array}{l}9.945 \mathrm{C} \\
\pm 1.000\end{array}$ & $\begin{array}{c}9.111 \text { ED } \\
\pm 2.181\end{array}$ & $\begin{array}{l}7.950 \mathrm{D} \\
\pm 2.604\end{array}$ \\
\hline & 2 & $\begin{array}{c}14.120 \mathrm{~A} \\
\pm 2.007\end{array}$ & $\begin{array}{c}13.000 \mathrm{AB} \\
\pm 2.449\end{array}$ & $\begin{array}{c}12.773 \mathrm{AB} \\
\pm 4.000\end{array}$ & $\begin{array}{c}11.117 \mathrm{BC} \\
\pm 3.604\end{array}$ & $\begin{array}{l}9.973 \mathrm{C} \\
\pm 1.839\end{array}$ & $\begin{array}{l}9.952 \mathrm{C} \\
\pm 2.009\end{array}$ & $\begin{array}{c}9.124 \text { CD } \\
\pm 2.035\end{array}$ & $\begin{array}{l}7.950 \mathrm{D} \\
\pm 2.604\end{array}$ \\
\hline \multirow{2}{*}{$25 / 10$} & 1 & $\begin{array}{c}14.097 \mathrm{~A} \\
\pm 5.311\end{array}$ & $\begin{array}{c}12.920 \mathrm{AB} \\
\pm 3.100\end{array}$ & $\begin{array}{c}12.815 \mathrm{AB} \\
\pm 4.060\end{array}$ & $\begin{array}{c}11.053 \mathrm{BC} \\
\pm 1.405\end{array}$ & $\begin{array}{c}10.195 \text { CD } \\
\pm 2.223\end{array}$ & $\begin{array}{c}9.981 \text { CD } \\
\pm 2.050\end{array}$ & $\begin{array}{c}9.130 \mathrm{CD} \\
\pm 2.000\end{array}$ & $\begin{array}{l}8.297 \mathrm{D} \\
\pm 3.009\end{array}$ \\
\hline & 2 & $\begin{array}{c}14.116 \mathrm{~A} \\
\pm 4.209\end{array}$ & $\begin{array}{c}13.025 \mathrm{~A} \\
\pm 4.305\end{array}$ & $\begin{array}{c}12.987 \mathrm{~A} \\
\pm 4.214\end{array}$ & $\begin{array}{c}10.984 \mathrm{~B} \\
\pm 2.333\end{array}$ & $\begin{array}{c}10.210 \mathrm{BC} \\
\pm 2.180\end{array}$ & $\begin{array}{c}10.017 \text { BCD } \\
\pm 3.110\end{array}$ & $\begin{array}{c}9.125 \text { CD } \\
\pm 2.107\end{array}$ & $\begin{array}{l}8.297 \mathrm{D} \\
\pm 3.009\end{array}$ \\
\hline
\end{tabular}


Moustafa, A.M.

\begin{tabular}{|c|c|c|c|c|c|c|c|c|c|}
\hline $\begin{array}{c}\text { Tot. } \\
\text { gm./colony/ } \\
\text { 23 days }\end{array}$ & 2 & 109.43 & 101.17 & 100.95 & 88.10 & 82.00 & 79.23 & 72.47 & 64.97 \\
\hline
\end{tabular}


J. Plant Prot. and Path., Mansoura Univ., Vol.5 (3), March, 2014

\begin{tabular}{|c|c|c|c|c|c|c|c|c|c|}
\hline \multirow{2}{*}{ Mean } & 1 & $13.68 \mathrm{~A}$ & $12.65 \mathrm{~B}$ & $12.62 \mathrm{~B}$ & $11.01 \mathrm{C}$ & $10.25 \mathrm{D}$ & $9.90 \mathrm{E}$ & $9.06 \mathrm{~F}$ & $8.12 \mathrm{G}$ \\
\cline { 2 - 10 } & 2 & $13.76 \mathrm{~A}$ & $12.77 \mathrm{~B}$ & $12.72 \mathrm{~B}$ & $11.11 \mathrm{C}$ & $10.33 \mathrm{D}$ & $9.99 \mathrm{E}$ & $9.07 \mathrm{~F}$ & $8.12 \mathrm{G}$ \\
\hline $\begin{array}{l}\text { Deviation } \\
\text { to control } \\
(\%)\end{array}$ & 1 & +68.43 & +55.70 & +55.37 & +35.59 & +26.20 & +21.94 & +11.54 & 0.00 \\
\cline { 2 - 10 } & 2 & +69.46 & +57.27 & +56.56 & +36.78 & +27.18 & +23.03 & +11.98 & 0.00 \\
\hline \multicolumn{2}{|c|}{ General Mean } & $13.72 \mathrm{~A}$ & $12.71 \mathrm{~B}$ & $12.67 \mathrm{~B}$ & $11.06 \mathrm{C}$ & $10.29 \mathrm{D}$ & $9.95 \mathrm{E}$ & $9.08 \mathrm{~F}$ & $8.12 \mathrm{G}$ \\
\hline
\end{tabular}

Means followed by the same letter at the same column are not significant differences at 5 $\%$ level of probability 